\title{
Oil collecting bees and Byrsonima cydoniifolia A. Juss. (Malpighiaceae) interactions: the prevalence of long-distance cross pollination driving reproductive success
}

\author{
MORGANA S. SAZAN ${ }^{1}$, ANTONIO DIEGO M. BEZERRA ${ }^{2}$ and BRENO M. FREITAS $^{2}$ \\ ${ }^{1}$ Faculdade de Filosofia, Ciências e Letras de Ribeirão Preto, USP, Departamento de Ciências Biológicas, \\ Entomologia, Bloco 9, 14040-901 Ribeirão Preto, SP, Brasil \\ ${ }^{2}$ Universidade Federal do Ceará, Departamento de Zootecnia, CCA, \\ Campus Universitário do Pici, Bloco 808, 60356-000 Fortaleza, CE, Brasil
}

Manuscript received on February 8, 2013; accepted for publication on June 12, 2013

\begin{abstract}
Oil-collecting bees are the natural pollinators of oil-flower plants, but little is known about the pollination process and the effectiveness of their pollination service to the reproductive success of their host plants. In species of Byrsonima the reproductive system have been described as auto-compatible or self-incompatible. We studied the reproductive system of Byrsonima cydoniifolia, the fructification by means of short, medium and long-distance cross pollinations, the morphology and floral biology and the pollination interactions with species of oil-collecting bees. By means of controlled pollinations we found self-incompatibility caused by abortion of most self-pollinated flowers and demonstrated that the prevailing cross pollination ensuring the reproductive success of B. cydoniifolia is the long-distance cross pollination and Centridini bees; Epicharis nigrita, particularly, are the pollinators promoting the gene flow between genetically distinct populations.
\end{abstract}

Key words: Centridini, Epicharis nigrita, oil flowers, pollinators, self-incompatibility.

\section{INTRODUCTION}

Oil-collecting bees are recognized as the natural pollinators of plant species which flowers secrete oils as rewards to floral visitors (Michener 2007). This association is possible due to morphological and behavioral adaptations between bees and flowers probably resulting from the evolutionary history of both groups (Neff and Simpson 1981, Alves dos Santos et al. 2007), in which they developed an interdependance where plants need the bees to pollinate their flowers and produce seeds to ensure the next generation, and bees rely on these flowers to obtain floral oils used for larval feeding and nest

Correspondence to: Morgana Silveira Sazan

E-mail:mssazan1511@usp.br building (Vogel 1990, Schlindwein and Martins 2000). Whereas such relationship is well documented and described in literature (Vogel 1974, Anderson 1979, Sazima and Sazima 1989), little is known about the pollination process and the effectiveness of the oil-collecting bees pollination service to the reproductive success of their host plants.

Oil-producing flower species can either be self-compatible or self-incompatible. For example, in Byrsonima, a genera belonging to the Familiy Malpighiaceae whose species show a strong association with Centridini bees (Gottsberger 1986, Teixeira and Machado 2000, Neves and Viana 2001, Gaglianone 2005, Smith et al. 2006), there are reports of self-compatibility in ten species (Barros 
1992, Benezar and Pessoni 2006, Ribeiro et al. 2006, Mendes et al. 2011) and self-incompatibility in another five species (Pereira and Freitas 2002, Rêgo and Albuquerque 2006, Costa et al. 2006, Bezerra et al. 2009, Dunley et al. 2009, Mendes et al. 2011). Although a self-compatible plant can set seeds originating from its own pollen, cross pollination promoted by floral visitors can enhance fruit and seed set, significantly increasing its reproductive success (Roubik 2002, Liu et al. 2013). However, self-incompatible species depend directly on pollen vectors to cross pollen between individuals genetically distinct, and long-distance dispersion pollen associated to self-incompatibility and to the behavior of pollinators provinding cross pollination, possibly potentiates the formation of fruits with viable seeds which consequently affect genetic variation (Aylor 2003, Larrinaga et al. 2009). Many oil-collecting bees are capable of carrying pollen grains over long distances (Schlindwein and Martins 2000 ), but there is no information about their role in the pollination of self-incompatible oil-flower plants.

Research studies about pollen dispersal and cross pollination with detachment between the pollen donor and recipient plants were carried out mainly with plants of commercial interests aiming to improve the purity of seeds (Raynor et al. 1972, Bannert and Stamp 2007). In this study we investigated the pollination of a wild oilflower species, Byrsonima cydoniifolia A. Juss. (Malpighiaceae), its interactions with oil-collecting bees and the bees' role in the plant's reproductive success through short-, intermediate- and longdistance cross pollination.

Byrsonima cydoniifolia, known as canjiqueira, is a native species to Bolivia and Brazil, occurring extensively in the Pantanal region (Mamede 2012). The plant presents massive blooming and offers important resources to oil-collecting bees while their fruits are consumed by a variety of birds, the tapir (Tapirus terrestris) and other animals. In addition to their medicinal properties and potential for commercial exploitation in natura, the fruits are processed into juice, jelly, ice cream and licor preparations (Pott and Pott 1994, Paes et al. 2012).

\section{MATERIALS AND METHODS}

STUDY AREA

The experiments were carried out from September 2008 to April 2009 in the region of Passo do Lontra (19 $34^{\prime} \mathrm{S}$ and $57^{\circ} 02^{\prime} \mathrm{W}$ ), Pantanal do Miranda, in the State of Mato Grosso do Sul, Brazil, where sandy soils and the Cerrado vegetation prevail.

Pantanal is one of the biggest flood plains of the world, characterized by seasonal ebbs and flows (Pott and Pott 2004) and delimitated in physiographic sub-regions classified according to their prominence, the kind of soil, phytogeography and hydrology (Silva and Abdon 1998). The weather is sub-humid tropical Aw of Köppen (Köppen 1948), with two well-marked seasons, a rainy one from October to March and a dry one from April to September, with annual average rainfall of $1400 \mathrm{~mm}$ and annual average temperature ranging from $21^{\circ} \mathrm{C}$ (winter) to $32^{\circ} \mathrm{C}$ (summer) (Pott and Pott 2004). The flora presents species which are characteristics of various phytogeographic areas, such as the Amazon and the Atlantic forests, the Cerrado and the Chaco (Pott and Pott 2004).

Many plant species in Pantanal have cluster distributions, forming extensive areas with the dominance of one species (mono-specific formations) determined by the kind of soil, water regime (dry and wet) and morphological adaptations of the plant species, tolerant to water flooding or not (Pott and Pott 2004). These areas receive regional denomination according to the vernacular name of the species (Silva and Abdon 1998). "Canjiqueiral" has homogeneous vegetation type composed by a shrubby stratum dominated almost exclusively by the canjiqueira (B. cydoniifolia), and a herbaceous vegetation composed by grasses, sedges and other herbs. The B. cydoniifolia species is distributed 
along the Amazonian region, Bolivia and central part of Brazil, and its height ranges from 1 to 5 meters (Pott and Pott 1994). Blooming begins in mid-September and continues until the end of December, with the peak of flower production in November and fructification starting in December and extending to the end of April. The fruit is totally developed in four months (Pott and Pott 1994).

In our study area, we chose three $B$. cydoniifolia canjiqueirais, denominated canjiqueiral (i), canjiqueiral (ii) and canjiqueiral (iii), (areas: 2000, 680 and $900 \mathrm{~m}^{2}$ respectively). The straight-line distance between the canjiqueirais (i) and (ii) was of $1.9 \mathrm{~km}$, between (i) and (iii) of $7.8 \mathrm{~km}$, and between (ii) and (iii) of $5.9 \mathrm{~km}$. In these canjiqueirais the average $B$. cydoniifolia density is eight individuals $\backslash 10 \mathrm{~m}^{2}$. In canjiqueiral (i) individuals of B.cydoniifolia occured sparsed among trees of Tabebuia aurea (Silva Manso) Benth. ex Hook.f. ex S. Moore (Bignoniaceae). In canjiqueirais (ii) and (iii) B. cydoniifolia occured alongside the Couepia uiti (Mart. and Zucc.) Benth. Ex Hook.f. (Chrysobalanaceae). During this study only $C$. uiti bloomed simultaneously to B. cydoniifolia flowering in the three canjiqueirais. Vouchers (BRAHMS 24789) of the plant species were prepared and deposited at the herbarium of the Universidade Federal de Mato Grosso do Sul (CGMS/UFMS), in Campo Grande.

\section{MORPHOLOGY AND FLORAL BIOLOGY}

At the beggining of the 2008 flowering season (September), we marked 30 inflorescences from six individuals to investigate $B$. cydoniifolia floral biology. We recorded the time of anthesis, anthers dehiscence, petal colors, flower lifespan, number of buds and open flowers per inflorescence.

We measured stigma receptivity using the hydrogen peroxide reaction on the stigmatic surface ( $n=30$ flowers). Treated stigmas were observed with the aid of a hand magnifying glass and we considered stigmas presenting effervescent response, to be receptive (Teixeira and Machado 2000).
We estimated the proportion of viable pollen grains per anther using cytoplasmatic staining technique by acetic carmine and only considered stained grains to be viable pollen grains (Munin et al. 2008). We also collected pollen grains from fifteen individuals, sampling flowers in preanthesis $(\mathrm{n}=15)$, in anthesis $(\mathrm{n}=15)$ and postanthesis $(n=15)$ from each plant. Pollen viability (\%) was then assessed under a microscopy inspecting 150 pollen grains per slides ( $\mathrm{n}=45$ slides). For morphometry and morphology we used 30 flowers fixed in alcohol $70 \%$ and we described the floral type, the androecium and gynoecium. We also measured the length of elaiophores $(n=30)$ and diameter and length of corolla and calyx $(n=30)$. The mean values presented are followed by standard deviations.

\section{FLORAL VISITORS}

We observed the foraging behavior of $B$. cydoniifolia flower visitors in the three canjiqueirais studied. These observations were taken every other day in a total of $360 \mathrm{~h}$ by means of visual monitoring near the plants.

In canjiqueiral (i) only, we selected five $B$. cydoniifolia individuals and chose at random $1 \mathrm{~m}^{2}$ of the canopy of each plant to record the number of inflorescences, open flowers, number and average duration of visits to flowers, floral visitors frequency, as well as the result of these visits (pollination when visitors touched the reproductive organs or theft - when visitors removed rewards not touching the reproductive organs). Data about floral visitors were taken during $20 \mathrm{~min}$ periods intercalated by 40 min intervals from 05:30 to 18:30h, over five days.

We determined the bee occurrence frequency (OF) using the formula $\mathrm{OF}=$ (number of occurrences of a species/ total number of occurrences) $\times 100$. Results over or equal to $50 \%$, were classified as very frequent (VF); between 25 and $50 \%$ as frequent (F) and below 25\% as less frequent (LF) (Buschini 2006). Means presented in the results are followed by standard deviations. 
Bees visiting B. cydoniifolia flowers were collected using sweep nets, killed, pinned and sent for identification by bee taxonomists. Floral visitors were also classified according to the size as being medium to large (body length $\geq 12 \mathrm{~mm}$ ) or small (body length $<12 \mathrm{~mm}$ ) (Bezerra et al. 2009). Later, floral visitors were placed in the zoological collection of the Universidade Federal de Mato Grosso do Sul.

\section{REPRODUCTIVE SYSTEM}

We studied the reproductive system of $B$. cydoniifolia in the three canjiqueirais through controlled pollination in marked inflorescences and buds bagged with TNT bags (cotton threads and cellulose fiber fabric) for mainpulation at anthesis. Treatments used were: (1) hand self-pollination; (2) geitonogamy; (3) apomixy (emasculating flowers); (4) autopollination (spontaneous self-pollination); (5) hand cross pollination with pollen grains coming from plant donors at different distances to the pollinated plant: pollen from the closest neighbor (5 to $20 \mathrm{~m}$ ), pollen from a neighbor at an intermediate distance $(100 \mathrm{~m})$ and pollen from the most distant neighbor $(>1000 \mathrm{~m})$ and (6) natural pollination (control). Fructification was recorded after full fruit development. All treatments were applied to 30 individuals found in the three canjiqueirais. The number of flowers used in each treatment is presented in Table I.

We then calculated the self-incompatibility index (SII $=\%$ fruits formed per hand selfpollinated flowers/flowers hand cross-pollinated) and the reproductive effectiveness $(\mathrm{RE}=$ percentage of fruits formed in natural conditions/percentage of fruits formed by cross-pollination) (Oliveira and Gibbs 2000). Proportions found in the controlled treatment experiments were tested for significant differences through chi-square $\left(\chi^{2}\right)$ tests.

\section{RESULTS}

MORPHOLOGY AND FLORAL BIOLOGY

Byrsonima cydoniifolia flowers were hemaphrodite, zygomorphic, pentamerous and diplostemonous and presented in terminal racemes. Petals were yellow, ungiculated and free among them. The uppermost petal, called standard or guide, distinguished from the others for being smaller, thicker and for distending totally in relation to the others which were concave (Table I).

The calyx was green in young floral buds, turning to yellow in pre-anthesis buds. In all inspected flowers we found ten epithelial eliptic oilproducing glands per flower. The androecium was yellow and formed by ten stamens whose anthers presented longitudinal dehiscence and densely haired filaments. Pollen grains were white and dry, showing $85.2 \%$ mean viability in pre-anthesis flowers $(\mathrm{n}=15), 87.6 \%$ during anthesis $(\mathrm{n}=15)$ and $66.83 \%$ in post-anthesis $(n=15)$. The gynoecium presented superior, tricarpellate, trilocular ovary, with one ovule per locule, three long hairless styles, acute at the apex, apart from each other and positioned slightly higher than the anthers. Morphological and biological measurements of the inflorescence and flower components are shown in Table I.

Buds in pre-anthesis were arranged facing the inflorescence base while flowers were well open towards their apex. Anthesis was asynchronous in distinct points on the inflorescence circumference and started at $05: 00 \mathrm{~h}$ when petals strained and the stamens separated from each other. At this moment, some anthers were already dehisced despite one or two petals still covering the reproductive structures. Then, the remaining petals unfolded, but the standard petal was the last to open and, at this stage, some pollen grains already accumulated on the stylet bases. Next, the three stigmas, already receptive, distended and separated from each other until forming an acute angle with the petals.

All elaiophores were functional since preanthesis and persisted during the whole period flowers were open and attractive to visitors for about two days. After that, anthers became dark and the petals turned redish and dried out progressively until total senescence. 
Elaiophores, stigmas and sepals were persistent during fruit development. After petal senescence, the sepals of fertilized flowers covered the reproductive structure to protect the fruit in formation.

TABLE I

Morphological and biological characteristics of Byrsonima cydoniifolia inflorescences and flowers.

\begin{tabular}{lcc}
\hline Flower characteristic & Sample size $(\mathrm{n})$ & Mean \pm s.d \\
\hline Buds per receme & 30 & $15.7 \pm 4.88$ \\
Flowers open per day & 30 & $5.23 \pm 2.54$ \\
Inflorescence length $(\mathrm{mm})$ & 30 & $5.65 \pm 9.25$ \\
Standard petal length $(\mathrm{mm})$ & 30 & $0.72 \pm 0.07$ \\
Other petals length $(\mathrm{mm})$ & 30 & $0.87 \pm 0.08$ \\
Corolla diameter $(\mathrm{mm})$ & 30 & $17.12 \pm 1.23$ \\
Corolla length $(\mathrm{mm})$ & 30 & $6.93 \pm 1.25$ \\
Calyx diameter $(\mathrm{mm})$ & 30 & $4.74 \pm 0.32$ \\
Calyx length (mm) & 30 & $3.78 \pm 0.32$ \\
Elaiophore length $(\mathrm{mm})$ & 30 & $0.22 \pm 0.02$ \\
Androecium length $(\mathrm{mm})$ & 30 & $0.48 \pm 0.03$ \\
Gynoecium length $(\mathrm{mm})$ & 30 & $0.50 \pm 0.04$ \\
\hline
\end{tabular}

FLORAL VISITORS

Sixteen bee species visited B. cydoniifolia flowers, mainly those belonging to the tribe Centridini (Apidae). Centris was the richest genus in species and Epicharis the most abundant in individuals. Epicharis nigrita predominated among the potential pollinator species of B. cydoniifolia (Table II) and was present in the $1 \mathrm{~m}^{2}$ parcels $(\mathrm{n}=5)$ at all studied times of the day (Figure 1). We recorded a mean number of $15.6 \pm 2.30$ inflorescences and $135.0 \pm$ 1.58 flowers per parcel.

All Centridini showed a similar behavior when collecting pollen or floral oils from B. cydoniifolia flowers (Table II). They approached inflorescences flying fast, landing on a flower using the neighbor flowers or the lower petals of the visited flower to get a foothold with their rear legs while hanging themselves to the standard petal by the mandibles. Then, the bee scraped the elaiophores for oils using the fore and middle legs. When collecting pollen, the bees vibrated the flight muscles while pressing their bodies against the anthers and acquired great amounts of pollen on their bodies, especially undeneath the metassoma and mesossoma. After that, the bees left the flowers and while hovering in front of the flower, they combed themselves using the middle and rear legs and packed this pollen in the scopas of their rear legs. Bees took between 4 and 6 seconds per visit when collecting pollen and 7 seconds to harvest oil. Independently of the resource collected (pollen or oil), the bees always contacted the reproductive flower structures and can be considered as pollinators of this plant species (Table II).

Males of Epicharis xanthogastra were also seen flying over the B. cydoniifolia bushes to establish territories in an atempt to mate females. Their flight consisted of loops forming an eigth over a bush and also flying between nearby bushes and gradually displacing other bee species as well.

Xanthopedia larocai landed directly on a petal or sepal, walked to the elaiophore and hung itself to the petal's pedicel using its mandibles. Then, it scrapped the elaiophores with its forelegs, collecting oil and transferring it to the scopas in their rear legs while still sitting on the flower. After colleting oil from most elaiophores, the bee walked to another flower in the same inflorescence or flew to a nearby inflorescence. Usually, this bee avoided landing on the flower's corola, staying outside the floral circunference. The bee only touched the flower's reproductive structures when collecting pollen. In this case, pollen was removed directly from anthers using the front and middle legs. After that, the bee cleaned itself rubbing the forelegs against the middle legs, and then passed the pollen to the rear legs.

Out of the 16 bee species observed to forage on B. cydoniifolia flowers, $40 \%$ only collected pollen. These bees were small sized species (Table II), which eventually touched the reproductive structures. Alepidoscelis imitatrix, Alepidocelis hamata and Exomalopsis analis landed on flowers and actively collected pollen grains directly from anthers removing them with their front and middle legs. 


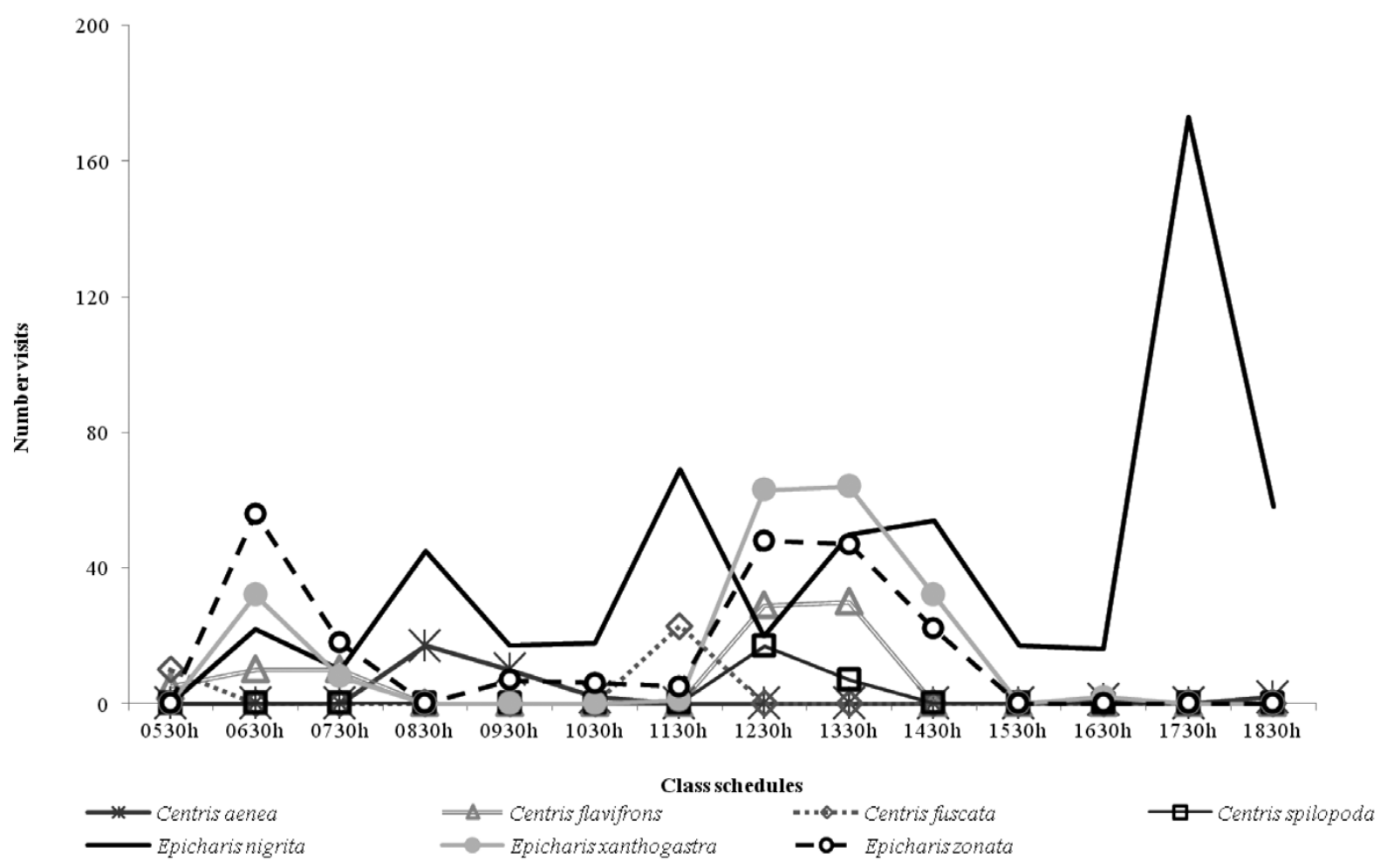

Figure 1 - Number of visits of the pollinators of Byrsonima cydoniifolia at different class schedules, in Pantanal sub-region of Miranda, Mato Grosso do Sul, Brazil.

Trigona spinipes and Tetragonisca angustula collected pollen by landing on petals, reaching the anthers, and moving their head up and down pushing pollen out of the anthers, assisted by the mandibles. Then, they collected the pollen displaced from the anthers using their front and middle legs and packed it in their corbiculae. Augochlora species also visited B. cydoniifolia landing on flowers and walking on petals to reach anthers. Pollen was harvested after the bee pressed the anther with its mandibles and squeezed the pollen out of the anther. Later, they collected the pollen grains using their forelegs and packed it in their reduced scopae, trocanter and fêmur of their middle and rear legs.

\section{REPRODUCTIVE SYSTEM}

All controlled pollination treatments formed fruits. Flowers under natural conditions (control) set the greatest number of fruits followed by the cross pollination treatments, long, short and intermediate distance, in this respective order (Table III). Treatments involving self pollen (autopollination, hand self pollination and geitonogamy) and apomixy set only a few fruits (Table III). In addition, apomixy was observed in only three flowers of two individuals. Self-incompatibility index (SII) was 0.17 and reproductive efficacy (RE) was 1.65.

The fructication success observed under natural conditions did not differ to that of long-distance cross pollination $\left(\chi^{2}=1.14 ; \mathrm{p}=0.33\right)$, but was significantly greater than the other treatments (Table III). The long distance cross pollination treatment, however, differed significantly to that of intermediate distance $\left(\chi^{2}=10.29 ; p=0.02\right)$, but not to the short distance one $\left(\chi^{2}=2.87 ; \mathrm{p}=0.12\right)$. The intermediate distance cross pollination and the short distance cross pollination treatments did not differ either $\left(\chi^{2}=2.24 ; p=0.18\right)$ between them (Table III). 
TABLE II

Floral visitors of Byrsonima cydoniifolia in Pantanal sub-region of Miranda, Mato Grosso do Sul. $\mathrm{BAD}=$ Body approximate dimension $; \pm \mathbf{s d}=$ mean \pm standard deviation; $\mathbf{R C}=$ Resource collected; $\mathbf{O}=$ Oil; $\mathbf{P}=$ Pollen; $\mathbf{T S}=$ touched stigma; $\mathbf{T A}=$ touched anthers; $\mathrm{OF}=$ Occurrence frequency - less frequent $(<25 \%)$, frequent (between $25-50 \%)$, very frequent $(>\mathbf{5 0} \%)$.

\begin{tabular}{|c|c|c|c|c|c|c|}
\hline \multirow[b]{2}{*}{ Species * } & \multicolumn{2}{|c|}{ BAD (mm) } & \multirow[b]{2}{*}{$\mathbf{R C}$} & \multirow[b]{2}{*}{ TA } & \multirow[b]{2}{*}{ TS } & \multirow[b]{2}{*}{ OF } \\
\hline & $\begin{array}{l}\text { length } \\
\mathbf{x} \pm \text { sd }\end{array}$ & $\begin{array}{l}\text { width } \\
\mathbf{x} \pm \mathbf{s d}\end{array}$ & & & & \\
\hline \multicolumn{7}{|l|}{ Apidae Centridini } \\
\hline Centris (Centris) flavifrons (Fabricius, 1775) & $21.7 \pm 0.22$ & $8.7 \pm 0.17$ & $\mathrm{O} / \mathrm{P}$ & + & + & 0.2 \\
\hline Centris (Centris) nitens Lepeletier, 1841 & $14.5 \pm 0.23$ & $5.39 \pm 0.3$ & $\mathrm{O} / \mathrm{P}$ & + & + & 1.3 \\
\hline Centris (Centris) varia (Erichson, 1848) & $15.3 \pm 0.48$ & $6.41 \pm 0.37$ & $\mathrm{O} / \mathrm{P}$ & + & + & 0.6 \\
\hline Centris (Centris) aff.spilopoda Moure, 1969 & $13.7 \pm 0.52$ & $5.44 \pm 0.32$ & $\mathrm{O} / \mathrm{P}$ & + & + & 8.2 \\
\hline Centris (Centris) aenea Lepeletier, 1841 & $16.39 \pm 1.09$ & $6.7 \pm 0.09$ & $\mathrm{O} / \mathrm{P}$ & + & + & 6.7 \\
\hline Centris (Trachina) aff.fuscata Lepeletier, 1841 & $17.25 \pm 0.27$ & $6.57 \pm 0.43$ & $\mathrm{O} / \mathrm{P}$ & + & + & 6.3 \\
\hline Epicharis (Epicharis) nigrita Friese, 1900 & $17.8 \pm 0.49$ & $7.09 \pm 0.16$ & $\mathrm{O} / \mathrm{P}$ & + & + & 59.5 \\
\hline Epicharis (Epicharoides) xanthogastra Moure \& Seabra, 1959 & $15.11 \pm 0.27$ & $5.79 \pm 0.31$ & $\mathrm{O} / \mathrm{P}$ & + & + & 4.8 \\
\hline Epicharis (Paraepicharis) zonata Smith, 1854 & $20.4 \pm 0.53$ & $7.3 \pm 0.1$ & $\mathrm{O} / \mathrm{P}$ & + & + & 8.4 \\
\hline \multicolumn{7}{|l|}{ Emphorini } \\
\hline Alepidosceles imitatrix (Schrottky, 1909) & $9.57 \pm 0.45$ & $3.72 \pm 0.39$ & $\mathrm{P}$ & + & - & 0.2 \\
\hline Alepidosceles hamata Moure, 1947 & $7.45 \pm 0.31$ & $3.05 \pm 0.22$ & $\mathrm{P}$ & + & - & 0.2 \\
\hline \multicolumn{7}{|l|}{ Exomalopsini } \\
\hline Exomalopsis (Exomalopsis) analis Spinola, 1853 & $6.3 \pm 0.09$ & $2.43 \pm 0.15$ & $\mathrm{P}$ & + & - & 0.6 \\
\hline \multicolumn{7}{|l|}{ Meliponini } \\
\hline Tetragonisca angustula (Latreille, 1811) & $4.54 \pm 0.08$ & $2.2 \pm 0.16$ & $\mathrm{P}$ & + & - & 0.4 \\
\hline Trigona spinipes (Fabricius, 1793) & $6.39 \pm 0.58$ & $2.95 \pm 0.2$ & $\mathrm{P}$ & & & 1.1 \\
\hline \multicolumn{7}{|l|}{ Tapinotaspidini } \\
\hline Xanthopedia larocai Moure, 1995 & $6.36 \pm 0.09$ & $2.46 \pm 0.15$ & $\mathrm{O} / \mathrm{P}$ & + & - & 0.4 \\
\hline \multicolumn{7}{|l|}{ Halictidae } \\
\hline Augochlora sp. Smith, 1853 & $8.15 \pm 0.19$ & $2.71 \pm 0.36$ & $\mathrm{P}$ & + & - & 0.6 \\
\hline
\end{tabular}

* According to Michener 2007.

\section{TABLE III}

Proportion between formed fruits and flowers used in controlled treatment applied in Byrsonima cydoniifolia and chi-square test $\left(\mathrm{X}^{2}\right)$ with statistical differences among the types of pollination treatment in Pantanal sub-region of Miranda, Mato Grosso do Sul, Brazil.

\begin{tabular}{lccc}
\hline \multicolumn{1}{c}{ TREATMENT } & FLOWERS/FRUITS & $\mathbf{\%}$ & $\boldsymbol{X}^{2} \mathbf{p}<\mathbf{0 . 0 5}$ \\
\hline Natural conditions & $2901 / 872$ & 30 & $\mathrm{a}$ \\
Long distance cross-pollination & $143 / 37$ & 26 & $\mathrm{a}, \mathrm{b}$ \\
Short distance cross-pollination & $137 / 24$ & 18 & $\mathrm{~b}, \mathrm{c}$ \\
Intermediate distance cross-pollination & $150 / 17$ & 11.3 & $\mathrm{c}$ \\
Autopollination (spontaneous self-pollination) & $286 / 14 *$ & 6 & $\mathrm{~d}$ \\
Hand self-pollination & $156 / 5$ & 3.2 & $\mathrm{~d}$ \\
Apomixy & $112 / 3$ & 3 & $\mathrm{~d}$ \\
Geitonogamy & $102 / 3$ & 2.9 & $\mathrm{~d}$ \\
\hline
\end{tabular}

Values with different letters are significantly different of $\mathrm{p}=0.05$.

* Formed fruit in only two individuals. 


\section{DISCUSSION}

Byrsonima cydoniifolia bears many morphological and biological characteristics that suggest a strong dependance on biotic pollinators, particularly bees. Its flower offers pollen and oil as rewards to floral visitors, and other features such as diurnal anthesis, yellow flowers, exposed reproductive structures and floral architeture to favor landing, suggest the melitophily syndrome (Faegri and Van De Pij1 1979).

Concentrated flowering, gradual and asynchronous availability of mature flowers and their different orientations in the inflorescence arrangement which facilitate the access to flower visitors, as observed in B. cydoniifolia, seem to be common characteristics to many species of the genus Byrsonima which rely on bee pollination, as reported by many authors (Barros 1992, Albuquerque and Rêgo 1989, Pereira and Freitas 2002, Teixeira and Machado 2000, Benezar and Pessoni 2006, Smith et al. 2006, Rêgo and Albuquerque 2006, Bezerra et al. 2009). In fact, B. cydoniifolia was visited by a range of floral visitors, all of them belonging to two bee Families.

It is well known that morphology and floral biology are of great importance to pollination success because both can directly influence to pollinator attractiveness, efficacy and, consequently, fruit formation (Freitas and Paxton 1998, Li et al. 2009). The morphology of B. cydoniifolia flowers presenting elaiophores arranged around the whole calyx, unguiculated petals which leave accessible space between them, and the thickness of the standard petal, allow floral visitors to hang themselves to the standard petal by their mandibles while pushing their legs between the other petals to reach the elaiophores (Anderson 1979, Vogel 1990, Ramalho and Silva 2002, Smith et al. 2006). Such caracteristics favor visits by bees specialized in collecting floral oils, like those of the tribe Centridini. Out of the 16 bee species visiting $B$. cydoniifolia, ten were oil-collecting bees and nine belonged to the Centridini.
In Pantanal, B. cydoniifolia probably constitutes a major oil source for the Centridini species observed in our study. This is especially true to E. nigrita, the most frequent species responsible for almost $60 \%$ of all flower visits and certainly the main pollinator of $B$. cydoniifolia flowers. This bee species has also been appointed as the major pollinator for other Byrsonima species, like $B$. intermedia and B. sericea (Gaglianone 2005, Dunley et al. 2009). In this study, E. nigrita visited flowers at any time of the day, however its presence on flowers peaked late in the afternoon. We believe this happened because there was a nest aggregation close to one of the studied areas, and probably $E$. nigrita females took advantage of this proximity to concentrate there their last foraging trips of the day.

The frequency and abundance of E. nigrita to flowers of $B$. cydoniifolia may be related to bee emergence in synchrony to the plant species blooming period. However, despite providing pollen and oil in their flowers $B$. cydoniifolia does not produce nectar, and adult bees also need carbohydrates for their survival (Danforth 2009). Therefore, the synchronopatry of B. cydoniifolia and $C$. uiti in the studied canjiqueirais seem to be a positive association in terms of B. cydoniifolia pollination carried out by Centridini bees, because $C$. uiti produces abundant nectar and potentially attracts both male and female of the Centridini bees which also visit B. cydoniifolia. In this study, in addition to recording females of all Centridini species, we also observed males of Centris spilopoda, Epicharis xanthogastra and Epicharis zonata collecting nectar in the flowers of C. uiti.

The presence of pollinators such as E. nigrita in areas where $B$. cydoniifolia occurs is crucial for the species reproduction. This is so, because our study showed that even though B. cydoniifolia can set fruits originating from self- and autopollination, geitonogamy and even apomixy, it is largely selfincompatible and the great majority of fruits produced derive from cross pollination. This was confirmed by the self-incompatibility index found. 
The low fruit set following autopollination and hand self-pollination observed to $B$. cydoniifolia was also reported to other seven Byrsonima species (Barros 1992) and total self-incompatibility in $B$. chrysophylla (Ribeiro et al. 2006). Only Benezar and Pessoni (2006) obtained a high percentage of fruit formation (44\%) by autopollination in $B$. coccolobifolia. Some fruit formations by auto or self-pollination are not rare in (predominantly) selfincompatible plant species and can be an important mean to ensure reproduction when the effective pollinators are scarce or not present at all (Munin et al. 2008). Apomixy does not seem to be common in B. cydoniifolia as well as other species of Malpighiacea; Sigrist and Sazima (2004) reported apomixy only to Banisteriopsis pubipetala among 11 species of this botanical family. Apomixy also seems to be rare among species of Cerrado and was observed only in Miconia albicans and Eriotheca pubencens out of 49 species studied by Oliveira and Gibbs (2000).

Because B. cydoniifolia presented to be a self-incompatible species, the transfer of pollen between genetically distinct individuals is necessary to increase fruit production and the species genetic variability. Therefore, it could be expected that cross pollination between plants growing far from each other would produce greater reproductive success. But studies carried out about pollen dispersion and cross pollination over different distances showed that due to temperature and wind interference little viable pollen reaches receptive stigmas at long distances and suggested that the longer the distance between the donor and the receptor plant, the lower is the efective fructification (Luna et al. 2001, Byrne and Fromherz 2003, Bannert and Stamp 2007). In our study however, the long distance cross pollination treatment $(>1000 \mathrm{~m})$ showed similar results to that of the natural condition treatment, proving that most of the pollination achieved by B. cydoniifolia results from long distance cross pollination. Other studies found similar results to ours; Ellstrand and Marshall (1985) working with Raphanus sativus (Brassicaceae) and Godt and Hamrick (1993) with Lathyrus latifolius (Fabaceae) found 18 and 46\% fruit formation to distances between 100-1000 m and $70 \mathrm{~m}$, respectively.

Our results suggest that Centridini bees are not only capable of pollinating oil-flower species, such as $B$. cydoniifolia, but are also capable of promotion a great proportion of long-distance cross pollination. According to Schlindwein and Martins (2000), some bees evolved their behavior and morphology, and adapted to the gathering of floral resources of difficult access as well as the exploitation of specific floral resources, and can carry pollen over relative long distances. Probably, larger Centridini can fly for longer periods of time and forage in longer trap lines carrying pollen between distant plants (Janzen 1971, Ohashi 2005, Ohashi et al. 2009). The bees Hoplitis adunca (11-13mm) and Chelostomara punculi (8-10mm), Megachilidae, were recorded foraging 450 to $1000 \mathrm{~m}$ from their nests (Zurbuchen et al. 2010) and all Centridini species observed in our study were larger than $13 \mathrm{~mm}$. Therefore, it is reasonable to assume that they can also forage at these distances or further.

Finally, we demonstrated that the natural pollination prevailing and ensuring the reproductive success of B. cydoniifolia is mainly due to longdistance cross pollination and Centridini bees, $E$. nigrita, particularly, are the pollinators promoting the gene flow between genetically distinct populations. A more detailed study tracking the foraging trips of these bees, assessing their specific pollination efficiency and investigating the pollen grains found on their bodies and nests could elucidate the possible existance of a proto cooperation between bees and B. cydoniifolia.

\section{ACKNOWLEDGMENTS}

We are thankful to Dr. Arnildo Pott for the identification of the botanical material; Dr. Gabriel 
Melo, Dr. Antônio Aguiar and Dr. Felipe Vivallo for identification of the bee species; and M.Sc. Alan Eriksson for help with statistical analyses. We would also like to thank Conselho Nacional de Desenvolvimento Científico e Tecnológico (CNPq) Brasília-Brazil for financial support, a M.Sc. scholarship to M.S. Sazan, a ITI scholarship to A.D.M. Bezerra and a research felowship to B.M. Freitas (\#305062/2007-7).

\section{RESUMO}

As abelhas coletoras de óleos são polinizadores naturais de plantas com flores que secretam óleos, mas pouco se conhece sobre o processo de polinização e efetividade dessas abelhas no sucesso reprodutivo dessas plantas. Nas espécies de Byrsonima o sistema reprodutivo tem sido descrito como autocompatível ou autoincompatível. Nós estudamos o sistema reprodutivo de Byrsonima cydoniifolia, a frutificação por meio de polinização cruzada de curta, média e longa distância, a morfologia e biologia floral e a interação de polinização com as espécies de abelhas coletoras de óleos. Por meio de tratamentos de polinização controlada encontramos autoincompatibilidade causada pelo aborto da maioria das flores autopolinizadas e demostramos que a polinização cruzada que prevalesce e assegura o sucesso reprodutivo de B. cydoniifolia, se deve principalmente à polinização cruzada de longa distância, e às abelhas Centridini; particularmente Epicharis nigrita, são os polinizadores que promovem o fluxo gênico entre as populações geneticamente distintas.

Palavras-chave: Centridini, Epicharis nigrita, flores secretoras de óleos, polinizadores, autoincompatibilidade.

\section{REFERENCES}

ANDERSON WR. 1979. Floral conservatism in neotropical Malpighiaceae. Biotropica 11: 219-223.

AlbuQuerque PMC AND RÊGo MM. 1989. Fenologia das abelhas visitantes de murici (Byrsonima crassifolia, Malpighiaceae). Bol Mus Paraense Emílio Goeldi Zool 5: 163-178.

Alves dos Santos I, Machado IC And Gaglianone MC. 2007. História natural das abelhas coletoras de óleo. Oecol Bras 11: 242-255.
AYLOR DE. 2003. Rate of dehydration of corn (Zea mays L.) pollen in the air. J Exp Bot 54: 2307-2312.

BANNERT M AND STAMP P. 2007. Cross-pollination of maize at long distance. Eur J Agron 27: 44-51.

BARros MAG. 1992. Fenologia da floração, estratégias reprodutivas e polinização de espécies simpátricas do gênero Byrsonima Rich (Malpighiaceae). Rev bras Biol 52: 343-353.

Benezar RMC AND Pessoni LA. 2006. Biologia floral e sistema reprodutivo de Byrsonima coccolobifolia (Kunth) em uma savana amazônica. Acta Amazon 36: 159-168.

BEZERRA ES, LOPES AV AND MACHADO IC. 2009. Biologia reprodutiva de Byrsonima gardneriana A. Juss. (Malpighiaceae) e interações com abelhas Centris (Centridini) no Nordeste do Brasil. Rev bras Bot 32: 95-108.

BUSCHINI MLT. 2006. Species diversity and community structure in trap-nesting bees in Southern Brazil. Apidologie 37: 58-66.

Byrne PF AND Fromherz S. 2003. Can GM and non-GM crops coexist? Setting a precedent in Boulder County, Colorado, USA. Food Agric Environ 1: 258-261.

Costa CBN, Costa JAS And Ramalho M. 2006. Biologia reprodutiva de espécies simpátricas de Malpighiaceae em dunas costeiras da Bahia, Brasil. Rev Bras Bot 29: 103-114.

DANFORTH B. 2009. Bees. Curr Biol 17: 156-161.

Dunley BS, Freitas L And Galetto L. 2009. The reproduction of Byrsonimasericea (Malpighiaceae) in fragmented habitats of the Restinga of Southeastern Brazil. Biotropica 41: 692-699.

ELLSTRAND NC AND MARSHALL DL. 1985. Interpopulation gene flow by pollen in wild radish, Raphanussativus. Am Nat 126: 606-616.

FAEGRI K AND VAN DER PIJL L. 1979. The principles of pollination ecology. Sinauer Associates, London, $244 \mathrm{p}$.

FreitAs MB AND PAXTON R. 1998. A comparison of two pollinators: the introduced honey bee Apis mellifera and an indigenous bee Centris tarsata on cashew Anacardium occidentale in its native range of NE Brazil. J Appl Ecol 35: 109-121.

GAGLIANONE MC. 2005. Nesting biology, seasonality, and flower hosts of Epicharis nigrita (Friese, 1900) (Hymenoptera: Apidae: Centridini), with a comparative analyses for the genu. Stud Neotrop Fauna and Environ 40: 191-200.

GodT MW AND HAMrICK JL. 1993. Patterns and levels of pollen-mediated gene flow in Lathyrus latifolius. Evolution 47: 98-110.

GotTSBERGER G. 1986. Some pollination strategies in neotropical savannas and forest. Plant Syst Evol 152: 29-45.

JANZEN DH. 1971. Euglossine bees as long-distance pollinators of tropical plants. Sci 171: 203-205.

KöPPEN W. 1948. Climatologia. Fondo de Cultura Economica. Buenos Aires, $478 \mathrm{p}$.

LARrinaga AR, GUITIÁN P, GARRIDO JL AND GUITIÁN J. 2009. Floral morphology and reproductive success in herkogamous Narcissus cyclamineus (Amaryllidaceae). Plant Syst Evol 278: 149-157. 
LI Y, QUAN Q AND SUN G. 2009. Effect of floral morphology on fruit set in Epimedium sagittatum (Berberidaceae). Plant Syst Evol 279: 51-58.

LiU ZJ, Chen LJ, LiU KW, Li LQ, RaO WH, Zhang YT, TANG GD AND Huang LQ. 2013. Adding Perches for Cross-Pollination Ensures the Reproduction of a SelfIncompatible Orchid. PLoS ONE [online] 8(1): e53695.

Luna S, Figueroa VJ, BALTAZAR MB, GOMEZ MR, TOWNSEND LR AND SCHOPER JB. 2001. Maize pollen longevity and distance isolation requirements for effective pollen control. Crop Sci 41:1551-1557.

MAMEDE MCH. 2012. Byrsonima in Lista de Espécies da Flora do Brasil. Jardim Botânico do Rio de Janeiro.

Mendes FN, Rego MMC AND AlbuQuerque PMC. 2011. Fenologia e biologia reprodutiva de duas espécies de Byrsonima Rich. (Malpighiaceae) em área de Cerrado no Nordeste do Brasil. Biota Neotrop. [online] 11(4): 103-115.

MiChENER CD. 2007. The bees of the world. John Hopkins University Press, Baltimore, 992 p.

Munin RL, TEIXEIRA RC AND SigRIST MR. 2008. Esfingofilia e sistema de reprodução de BauhiniacurvulaBenth. (Leguminosae: Caesalpinioideae) em cerrado no CentroOeste brasileiro. Rev Bras Bot 31: 15-25.

NEFF JL AND SIMPSON BB. 1981. Oil-collecting structures in the Anthophoridae (Hymenoptera): morfhology, function, and use in systematics. J Kansas Entomol Soc 54: 95-123.

NeVEs EL AND VianA BF. 2001. Ocorrência de Epicharis bicolor Smith (Hymenoptera: Apidae: Centridini) nas Caatingas da margem esquerda do médio Rio São Francisco, Bahia. Neotrop Entomol 30: 735-736.

OHASHI K AND THOMSON JD. 2005. Efficient harvesting of renewing resources. Behav Ecol 16:592-605.

OHASHI K AND THOMSON JD. 2009. Trapline foraging by pollinators: its ontogeny, economics and possible consequences for plants. Ann Bot 103: 1365-1378.

OliveIRA PE AND GiBBS PE. 2000. Reproductive biology of wood plants in cerradão community of Central Brazil. Flora 195: 311-329.

Paes SV, SoARes LMP, Murakami MD, Dos SANTOS MJ, BARbosa, FFB AND NeVES SS. 2012. Ocorrência de Meloidogy neenterolobii em muricizeiro (Byrsonima cydoniifolia). Trop Plantpathol 37(3): 215-219.

PEREIRA JOP AND FREITAS BM. 2002. Estudo da biologia floral e requerimentos de polinização do muricizeiro (Byrsonima crassifolia L.). Rev Cienc Agron 33: 5-12.

Pott A AND PotT VJ. 1994. Plantas do Pantanal. EMBRAPACPAP, Brasília.

PotT A AND PotT VJ. 2004. Features and conservation of the Brazilian Pantanal wetland. Wetl Ecol Manag 12: 547-552.

RAmalho M AND Silva M. 2002. Flora oleífera e sua guilda de abelhas em uma comunidade de restinga tropical. Sitientibus 2: 34-43.
RAYNOR GS, OGDEN EC AND HAYES JV. 1972. Dispersion and deposition of corn pollen from experimental sources. Agron J 64: 420-427.

RÊGo MMC AND AlbuQuerQue PMC. 1989. Comportamento de abelhas visitantes do murici, Byrsonima crassifolia (L.) Kunth. Malpighiaceae. Bol Mus Paraense Emílio Goeldi, Zool 5: 179-193.

RÊGo MMC AND AlBuQuerQue PMC. 2006. Polinização do Murici, Ministério do MeioAmbiente, EDUFMA, São Luís, 104 p.

RibeIro E, RÊGo MMC AND MACHAdo IC. 2006. Aspectos da polinização de murici pitanga Byrsonima chrysophyla (Malpighiaceae). In: Rêgo MMC and Albuquerque PMC (Eds), Polinização do Murici, Ministério do Meio Ambiente, EDUFMA, São Luís, p 49-54.

RouBIK DW. 2002. The value of bees in coffee harvest. Nature 417: 708.

SAZIMA M AND SAZIMA I. 1989. Oil-gathering bees visit flowers of glandular morphs of the oil-producing Malpighiaceae. Botanica Acta 102: 106-111.

SCHLINDWEIN CAND MARTINS CF. 2000. Competition between the oligolectic bee Ptilothrix plumata (Anthophoridae) and the flower closing beetle Pristimerus calcaratus (Curculionidae) for floral resources of Pavonia cancellata (Malvaceae). Plant SystEvol 224: 183-194.

SIGRIST MR AND SAZIMA M. 2004. Pollination and reproductive biology of twelve species of neotropical Malpighiaceae: stigma morphology and its implications for breeding system. Ann Bot 94: 33-41.

SILVA JSV AND ABDON MM. 1998. Delimitação do Pantanal Brasileiro e suas sub-regiões. Pesqui Agropecu Bras 33: 1703-1711.

SMith RS, GUYOMARC'H S, MANDEL T, ReINHARDT D, KuHLemeier C AND Prusinkiewicz P. 2006. A plausible model of phyllotaxis. P Natl Acad Sci USA 103: 1301-1306.

TEIXEIRA LAG AND MACHADO IC. 2000. Sistema de polinização e reprodução de Byrsonima sericea DC (Malpighiaceae). Acta Bot Bras 14: 347-357.

Vogel, S. 1974. Ölblumen und ölsammelnde Bienen. Akad. Wiss. u. Lit., math.-nat. Kl. Tropische und subtropische Pflanzenwelt 7: 285-547.

VoGEL S. 1990. History of the Malpighiaceae in the light of the pollination ecology. Men New York Bot Gard 55: 130-142.

Zurbuchen A, Cheesman S, Klaiber J, Müller A, Hein S AND DORN, S. 2010. Long foraging distances impose high costs on offspring production in solitary bees. J Anim Ecol 79: 674-681. 